\title{
The Power of Legislative Hot Air: Informal Rules and the Enlargement Debate in the European Parliament
}

\section{STEFANIE BAILER AND GERALD SCHNEIDER}

Integration theorists disagree over the extent to which the European Parliament can substantially influence policy-making processes in the absence of formal agendasetting power. This article discusses the impact the European Parliament had on the current enlargement negotiations. Although the legislature does not yet possess the means to alter the stance of the European Council, it has tried to reverse the status quo through the use of its informal bargaining power. We argue based on a principal-agent framework of analysis that the effectiveness of this strategy is largely a consequence of the ability to speak with one voice. The article evaluates various mechanisms to help the European Parliament build a unified position. It refutes socialisation and specialisation theories, showing that party group pressure towards a unified position overrode national concerns and constituted a necessary precondition in the development of an integrationist attitude. A statistical analysis of the pre-bargaining positions inside the Foreign Affairs and Security Committee largely confirms the insights from qualitative interviews with participants and observers.

When in December 1997 the European Parliament (EP) opted for a more generous attitude towards applicant countries in central and eastern Europe than the Commission, several observers hastily qualified this step as another incidence of legislative hot air. In their view, the pro-integration stance of the legislature does not represent much more than the hypocritical attempt of a supranational agent which still does not possess any substantial power in the domain of foreign policy. Commissioner van den Broek tellingly used the word 'lyrics' to characterise the position of the Parliament.'

Stefanie Bailer is a Ph.D. student at the University of Konstanz; Gerald Schneider is Professor of Political Science in the Department of Politics and Management at the University of Konstanz.

A first version of this paper was presented at the NIG seminar on the European Parliament, 2-5 July 1998, in Enschede, Netherlands, and at two research seminars at the University of Konstanz. The comments by Simon Hix, Susanne Schmidt, Bernhard Steunenberg, George Tsebelis and the anonymous reviewers of this journal have been particularly helpful. We would also like to thank our interview partners in the European Parliament and the European Commission for their patience and support. They granted us permission to quote their opinions on condition that they would remain anonymous. Thus the numbers in the article do not correspond to the order in which they are listed in the appendix. 
This article takes issue with this interpretation, demonstrating how the legislature strategically tries to alter the status quo through the use of parliamentary debates. To overcome its lack of formal agenda-setting power, the legislature can increasingly rely on the political clout that it has gained in contrast to the much-criticised European Commission. Yet, to proceed efficiently, the European Parliament has to take a public stance that the other actors can only disregard at the risk of losing face. The success of this shaming strategy largely depends on the internal cohesion of the legislature and the costs that are afflicted on other institutional actors. This argument is reflected in the structure of the article, which presents the shaming strategy of the European Parliament in the first part and discusses the ways in which this strategy was achieved in the second part.

The position of the EP is all the more surprising since eastern enlargement poses major redistributional problems inside the European Union in general and the European Parliament in particular. We term the position of the EP integrationist, since it opted, in contrast to the Santer Commission, for an allinclusive round of negotiations linked to an increase in the EU budget. Most theories of legislative behaviour suggest that enlargement belongs to the issues where parliamentary voting largely follows national lines. In contrast to received wisdom, we show that the internal structure of the organisation's legislative arm rather than socialisation or specialisation effects strengthens the transnational tendencies in the legislature. Although this effect might not be planned, party groups in the EP effectively disciplined their members in an integrationist direction. In our opinion, the transnational groups are therefore responsible for weakening national influences within the EP. Our results also suggest that the current discussion over the role of socialisation in the European Parliament is misleading and based on the wrong dichotomies. ${ }^{2}$ Our quantitative analysis of the pre-negotiation attitudes of MEPs shows, in contrast to the implications of the socialisation hypothesis, that parliamentary newcomers rather than senior figures tend to opt for integrationist positions on the most crucial dimensions of the enlargement package. As other studies have shown, individual positions largely reflect the attitude of the home government. Yet, as shown in this article, when the decision moves to the plenary, party group pressure starts to suppress national preferences. Although MEPs are agents with both national and transnational principals, they are ultimately mainly influenced by the transnational incentive structure of the European Parliament.

The article is structured as follows: first, the theoretical literature on the European Parliament is reviewed and its insights compared with the controversy over the significance of redistribution in the US Congress. Next, an analytic framework is presented that allows the informal power resources of the European Parliament to be categorised in relation to other institutional 
actors such as the European Council and the Commission. A survey of the enlargement negotiations until spring 1998 precedes the analysis of the main hypotheses. The article concludes with some remarks over the extent to which the results from this case study can be generalised.

\section{NATIONAL INTERESTS AND LEGISLATIVE BEHAVIOUR IN THE EUROPEAN PARLIAMENT}

This article explores how the European Parliament tries to influence decisions in the absence of conditional agenda-setting power and in the presence of relatively distinctive national interests. To address this double challenge, we integrate some insights from the three main analytical strands in the theoretically inspired literature on the supranational legislature spatial models of legislative rules; quantitative voting studies and organisational studies of the Parliament. This study tries to reconcile the parallel literatures in an in-depth analysis of the reactions of the European legislature to the current enlargement round. Both qualitative and quantitative evidence is offered to bolster the claims that we derive from the analytic literature on the European Parliament.

\section{Strategic Behaviour in the Absence of Formal Power}

Spatial models of decision making in the European Union have explored the relative power of the legislature vis-à-vis other institutional actors. Although some of the derived effects are contested and disputed, most observers agree that the European Parliament has by and large profited from the recent constitutional reforms. ${ }^{3}$ In the domain of foreign policy making, the assent procedure (Art. O Treaty of the European Union) is the dominating mode of interaction. ${ }^{4}$ This rule yields the European Parliament veto power over the enlargement package that the European Commission and the European Council will eventually conclude with the different applicant countries. The ensuing distribution of power in the foreign policy domain implies on the one hand that the Parliament cannot directly influence the selection of the states that are considered to be ready for membership. This sort of agenda-setting behaviour is formally within the domain of the European Council and informally of the European Commission. The legislature can on the other hand employ the veto as a weapon of last resort threatening to kill a proposal if the other institutions fail to live up to its demands.

In the enlargement negotiations, the threat of a future veto is, however, not credible since the legislature will typically perceive the admission of a small number of states as an improvement over the status quo. Further, the European Parliament is also more promiscuous than the other institutional players with regard to the second important issue - the financing of the new 
widening round. The integrationist attitude on both dimensions implies that the European Parliament as a collective actor has to employ other parliamentary resources to influence the negotiation strategy of the European Union towards the eastern European applicant countries. Yet it can only opt for a more generous policy if it is able to move the status quo in the preferred direction. The necessary means for such a strategic move is that the European Parliament publicly denounces the other institutional actors for their lack of vision and altruism. When opting for an all-inclusive enlargement strategy, the EP could portray itself as an 'advocate of the Eastern Europeans states' who considers long-term European interests much more than the more egoistic institutions of the EU. To embarrass the Commission and the European Council is, however, only feasible if the European Parliament is able to act relatively cohesively and if it is costly to the member states to denounce the legislature. To overcome its lack of formal power, the legislature has to opt for what we call a 'shaming strategy' at an early decision-making stage. ${ }^{5}$ Since opposing the other actors after the conclusion of a treaty yields the impression of a lack of seriousness, the Parliament has to damage the position of the other participating actors during the drafting period of the accession negotiation stances.

Figure 1 summarises the potential strategies that the European Parliament can choose during the decision-making stage and its position vis$\grave{a}$-vis the other institutional actors of the European Union. We distinguish on the one hand the drafting stage of a negotiation stance from the ratification period of the different accession treaties. A further differentiation is made between two possible preference configurations in which the European Parliament is either more or less conservative than the European Council. We argue that a veto or a veto threat is only possible if the European Parliament is more conservative than the heads of governments of the member states. A blockade, conversely, is inefficient at the last decisionmaking stage if the European Parliament is more integrationist than the other decisive actors. In such a situation, opposition towards the course of the intergovernmentalist European Council will not represent more than hot air since the public will perceive demands by the European Parliament for the inclusion of other states as incredible. This means equally that an integrationist legislature can only try to influence the course of events in the

FIGURE 1

POSSIBLE STRATEGIES OF THE EUROPEAN PARLIAMENT

EP less integrationist

\section{Drafting stage}

Ratification stage
Veto threat

Veto
EP more integrationist

Shaming

Hot air 
foreign policy domain effectively if it is able to accuse the other institutional actors of the European Union of their alleged lack of generosity.

\section{Socialisation, Specialisation, and the Structure of the Parliament}

The success of a shaming strategy, however, largely depends on the presence of a unified position that can claim moral superiority over the more reluctant negotiation stance of the other actors. Such a cohesive integrationist outlook can become possible in three ways. First, the transnational socialisation process that members of the European Parliament experience might induce them to move towards a position that is more integrationist than the one of their governments. Second, becoming a member of the European Parliament and especially its Foreign Affairs Committee might be based on some kind of self-selection process which leads integrationist foreign policy experts to opt for a parliamentarian career in this domain. Third, the pro-integrationist behaviour could be a consequence of the disciplining effect that the party groups within the EP have on the legislators. We argue that party leaders or their whips try to streamline their groups on a position which most easily finds a consensus in their group. This streamlining effort enables them to demonstrate cohesiveness on a matter in which they do not have a formal say. While the first explanation is sociological, its alternatives are institutionalist in the sense that the division of labour within the European Parliament is supposed to affect policy outcomes.

Our first hypothesis that members of the European Parliament go progressively native in Brussels, Strasbourg and Luxembourg enjoys a rich tradition in the study of regional integration. ${ }^{6}$ However, the frequent attempts to uncover an empirical connection between the length of a mandate and the voting record of individual MEPs remains rather ambiguous. Although the evidence found in the analysis of roll call votes is modest at best, this literature has recently experienced a major revival through the import of constructivist theories. ${ }^{7}$ Some researchers anticipate that the transnational context of a supranational legislature induces politicians to switch from a national to an integrationist outlook, including the idea of an ever wider European Union with increased competencies.

The renaissance of this traditional sociological hypothesis has inspired Mark Pollack's critical assessment of the extant literature. ${ }^{8}$ He concludes that self-selection rather than socialisation is the important factor that might lead to tension between MEP behaviour and constituency preferences. However, this rejection of the hypothesis seems to be based on pure blackand-white reasoning. While it is highly likely that individuals with a favourable attitude towards the European Union become members of the organisation rather than integration sceptics, it would be inadequate to dismiss the possibility that newly elected members of the Parliament change 
their political positions partly based on their experiences and the consequent learning effects.

Furthermore, the negative results of previous tests of the socialisation hypothesis could also be a consequence of inadequate research designs. The exclusive reliance on roll-call votes seems especially critical to us. Studies that rely on the final behaviour of the members of the European Parliament cannot account for the confounding influence that incentive structures like party group pressure might have on individual MEPs. The analysis of roll-call votes ignores the process leading to the final voting of MEPs. To overcome this problem, we have analysed the original positions that the members of the responsible committee had on the two most salient dimensions of the enlargement package before they gave their final vote in December 1997.

The socialisation hypothesis is, on the other hand, in stark opposition to some influential studies on the US Congress that make us believe that redistributive interests are the primary influence on legislative behaviour. The pioneering study by Weingast and Marshall particularly supports the alternative that members of the responsible committees are largely driven by re-election considerations.' This hypothesis is especially relevant for the enlargement decision, since most observers have agreed that the accession of eastern and central European states necessitates reform in the financial structure of the European Union and thus poses thorny redistributional questions. Hix and Lord demonstrate that voting according to national lines can occasionally matter a great deal in the EP, although the ideological position seems to be of primary importance..$^{10}$ Yet voting according to national lines is hardly compatible with the main thrust of our argument that the European Parliament has been more integrationist than other EU institutions in the first decision on the eastern enlargement of the organisation. One factor that shields members of the European Parliament from supposedly overpowering constituency demands is proportional representation. ${ }^{11}$ Nevertheless, MEPs are still elected by nationally defined constituencies which expect a representation of their interests from MEPs.

Our second hypothesis refers to the effects of specialisation and points out that the generous attitude towards enlargement could, on the other hand, also result from the committee structure of the European Parliament. The division of labour between various powerful committees and the floor could further integrationist tendencies as long as specialisation matters more in the selection of committee members than the redistributive tendencies. If only integrationist MEPs were appointed to the Foreign Affairs Committee, clear support for the enlargement process within this committee would hardly be surprising. It is conceivable that MEPs, who already have a special interest and disposition for a certain field, choose to go to the relevant committee to promote their interest by drafting corresponding reports and trying to 
convince their colleagues of the importance of their topics. Consequently, a great number of former government members or members with foreign policy experience tend to go to the Foreign Affairs Committee. Previous studies on the specialisation hypothesis within the European Parliament have, however, come up with rather mixed results. Raunio shows that MEPs do not only submit questions which are within the domain of their committee. ${ }^{12}$ Therefore, one cannot draw the conclusion that the selection of committee members leads directly to 'specialisation' at the behavioural level. This seems to be the case at least for members of the Foreign Affairs and Security Committee and the related Subcommittees on Human Rights and Security and Disarmament. Although the impact of these committees on parliamentary voting behaviour seems to be limited, we investigate the specialisation hypothesis in our study.

Another possibility that would dampen the impact of redistributive interests derives from the transnational organisation of the European Parliament, which is our third hypothesis. Since voting against the majority of the party group affects the reputation of individual MEPs, they have to assess the costs of an internal loss of face versus the eventual sanctions they might face if the party group decision contradicts constituency interests. We thus expect that members of the European Parliament who would like to vote according to the constituency 'mandate' have to count on pressure from their party group. Raunio has shown that party group cohesion is surprisingly strong in the European Union. ${ }^{13}$ This might show that members of the European Parliament often care more about the internal party game than about their re-election prospects. Since the party groups are responsible for recruiting MEPs for a number of interesting positions, such as committee chairs or (Vice-)President of the EP, members of a group have a motive to behave according to the group line. Or, to put it into the parlance of modern microeconomic theory, individual MEPs are 'office seekers' and agents who have to fear the cost of a vote against the party group majority. Whips within the party groups accordingly remind members about the significance of certain votes, control the presence of party members during voting, and check their voting behaviour. Informal sanctioning mechanisms were, for instance, employed against members of the Christian-Democrat party group who had not taken part in the vote on monetary union in May 1998. In this case, the list of those present was distributed as a fax message to all members of their national group in the fraction.

Whether our hypotheses concerning socialisation, the eventual integrative tendencies of committee specialisation or party group pressure are the constitutive factors of the strategy of the European Parliament will be addressed in the subsequent sections. We examine first how the main institutional actors have dealt with the enlargement issue. 
THE ENLARGEMENT DEBATE IN THE COMMISSION AND THE EUROPEAN PARLIAMENT

The enlargement debate of the European Union started officially when the European Council affirmed the rules for membership at its summit meeting in June 1993. These so-called 'Copenhagen criteria' state that joining the European Union requires eventual member states to establish both democratic institutions and a functioning market economy. The heads of government delegated the evaluation of the individual applicant countries to the European Commission, which published its position on enlargement and other salient reform topics in July 1997 in a paper with the emphatic title 'Agenda 2000'..$^{\text {is }}$ The Commission stated in this 1,300-page document that enlargement negotiations should initially begin with six applicant countries, namely Cyprus, the Czech Republic, Estonia, Hungary, Poland and Slovenia. ${ }^{15}$

This official stance was quickly termed the ' $5+1$ ' position, since the Commission had already earlier indicated its willingness to start negotiations with Cyprus. An internal coalition headed by Dutch Foreign Affairs Commissioner van den Broek was responsible for the inclusion of Slovenia and Estonia; the President of the Commission, Jacques Santer, had originally opted for a more Nato-like 'three (Poland, Hungary, the Czech Republic) + one' approach. ${ }^{16}$ Concerning the costs of enlargement, the Commission proposed to keep the EU budget fixed at the ceiling of 1.27 per cent. ${ }^{17}$ The additional costs were to be carried by thorough reforms of the agricultural, structural and cohesion funds.

The response to the enlargement blueprint by the Commission ranged from understandable enthusiasm among the chosen applicants to frustration among the excluded applicants. ${ }^{18}$ The reactions by the member states were equally mixed. The most severe quarrels broke out at the Finance Ministers' meeting in July in Brussels and in September in Mondorf (Luxembourg). German Finance Minister Theo Waigel and his Dutch colleague Gerrit Zalm suggested that cuts in the structural and cohesion funds were the appropriate means to finance eastern enlargement. They also insisted on the Commission proposal that aimed at keeping the 1.27 per cent ceiling in the EU budget. ${ }^{19}$ Unsurprisingly, the main victims of such a decision, Spain, Portugal, Greece and, to a lesser extent, Ireland, argued strongly against the German-Dutch proposal and implied that an increase in the budget ceiling would not be as harmful to them as a cut in the funds.

The question of how many countries should be included in the enlargement negotiations was a major source of conflict when the foreign ministers met in Mondorf in October 1997. Whereas some bigger member states such as Britain, France and Germany opted for the '5+1' approach, the southern and Scandinavian member states preferred the more generous ' $10+1$ ' option which later came to be known as the 'regatta' solution. This 
analogy with a boat race expresses that all applicant would 'start' simultaneously in the negotiations. Solidarity was, however, not the only motivation behind the all-inclusive attitude of some member states. They also hoped to buy time and prolong the enlargement negotiations through the increased complexity that the negotiations with the additional applicants would create, not least because they feared negative side-effects for their own countries from the enlargement. ${ }^{20}$

Belgium, Italy and France advanced another contested issue when they linked the enlargement debate to the process of internal reform. They insisted that a new distribution of the voting weights in the Council of the European Union and a reconsideration of the number of commissioners were necessary preconditions before the next enlargement could take effect. Some critics feared the real intention of this proposal was to slow down the enlargement process because these measures had been contested for a long time. 'It would not be politically correct to oppose their membership [of the former communist countries] openly. Instead, the French and Belgians mask their doubts by demanding endless reforms to voting procedures.'21

Similar disputes overshadowed the discussions in the European Parliament. Although the 'representatives of the European peoples' were not granted formal power, they tried to influence the course of events at least after 16 July 1997, when Jacques Santer presented Agenda 2000 in Strasbourg. The responsible Committee for Foreign Affairs, Security and Defence had already decided in June 1997 that two of its members, Arie Oostlander (NL/PPE) and Enrique Barón Crespo (E/PSE), should draft reports on 'A Strategy for Enlargement' and 'The Effects on the Policies of the Union' respectively. ${ }^{22}$

A speciality of the synthesising Oostlander/Baron Crespo report was the recruitment of 11 rapporteurs for individual country reports for each applicant state. ${ }^{23}$ The country reports were proportionally distributed among the political group in accordance to their relative strength. ${ }^{24}$ Yet, against this backdrop, certain national preferences appeared to matter in the selection of the rapporteurs. While an Italian MEP wrote on Slovenia and a Finn as well as a Dane were responsible for two Baltic states, a French rapporteur was chosen for Romania and two Germans for Poland and Hungary respectively. At the same time, the Budget Committee asked Joan Colom i Naval (E/PSE) to draft a report on 'Agenda 2000 - Framework for the Union for the Period 2000-2006 and the Future Financing of the Union' ${ }^{25}$ The reports from the Foreign Affairs Committee and from the Budget Committee were treated together so that the discussion and vote on them could take place simultaneously on 3 and 4 December 1997.

The Foreign Affairs Committee discussed the Oostlander/Barón Crespo report during seven sessions. Since the members of the Committee had 
highly different opinions on the two main issues, they voted on no less than 506 amendments to this draft report during the last of these sessions. ${ }^{26}$ The dispute on the enlargement strategy and the future financing of the European Union cut across the party groups in the EP. No clear camps could consequently be distinguished at the beginning of the discussion in summer 1997. In general, however, most members of the Committee opted for a more visionary approach than the one proposed by the Commission, stressing that the conditions for accession should not so much depend on the economic but rather on the political performance of the respective countries. As one of our interview partners told us, 'Le choix, c'est le choix politique. On a mis en evidence plutôt l'evidence politique' (IP 2).

The Socialist Group was completely split on the ' $5+1$ ' and the 'regatta' approach: on the one side stood a fraction of German Social Democrats led by the former President of the Parliament, Klaus Hänsch, joined by members of the British Labour Party. ${ }^{27}$ Their opponents, mainly Spanish, Italian and French colleagues, intended to opt for ' $10+1$ '. Before the vote in the Foreign Affairs Committee, the ' $5+1$ ' supporters won the majority in a vote on that issue in the group. ${ }^{28}$ Yet in the Foreign Affairs Committee vote on the Oostlander/Barón Crespo report, the otherwise dominant Socialists lost by a slight margin so that the ' $10+1$ ' approach prevailed. The budget question led to a similar division between members of parliaments from net contributor countries versus legislators from the southern members. The group finally agreed on the paragraph in the Colom i Naval report which said that the 1.27 per cent was no real estimate for the future financial demands of the Union. ${ }^{29}$

The Group of the European People's Party (PPE) sought to give a coherent position during the discussion, so it fought for a common position in a similar but less public way than the Socialists. The majority of the group favoured the 'regatta' approach, but they stood against a minority of Austrians, Swedes and Finns who would have rather opted for the more modest ' $5+1$ ' option. The party group finally voted in favour of the encompassing ' $10+1$ ' view. ${ }^{30}$

Although the EPP managed to gain the majority in the Foreign Affairs Committee, the Christian Democrats also realised during the days leading up to the final vote in the plenary on 4 December 1997 that the majority supporting the 'regatta' approach could be unstable. They therefore suggested a compromise amendment with a formula in which the European Parliament asked the European Council to start the enlargement process with a common act for all countries, to begin an intensified enlargement and accession process with ' $10+1$ ' countries and to restrict the intensive intergovernmental negotiations to ' $5+1$ ' countries. ${ }^{31}$ This compromise was very close to the resolution of the Foreign Affairs Committee and what the Chairman of the Committee of Foreign Affairs, Tom Spencer (UK/PPE), 
called the 'Russian dolls approach'. ${ }^{32}$ In financial matters, the group had problems similar to the Group of the Party of European Socialists (PSE), as members from southern states insisted on a generous budget approach. Representatives from contributor countries, by contrast, were largely against this opinion. The smaller party groups were equally divided. The Group Union for Europe (UPE), for instance, claimed to be in favour of the 'regatta' approach and the more magnanimous budget option during the debate in the plenary. ${ }^{33}$ In the final vote, however, only half of the group supported the report, whereas the other half abstained, amongst others group leader Pasty, who was strongly opposed to the critical comments on Slovakia. ${ }^{34}$ The Liberals in return were rather uniform in their support of the ' $5+1$ ' option. ${ }^{35}$ On budget matters they were in favour of keeping the 1.27 per cent line, but were not radical about it. ${ }^{36}$ The Green Group finally

FIGURE 2

PARTY GROUP POSITIONS TOWARDS THE NUMBER OF INVITED APPLICANTS AND THE FINANCIAL ASPECTS OF THE ENLARGEMENT PROJECT

Number of Rejection of Commission 'Russian dolls' 'Regatta'

applicants official proposal proposal approach approach

$(5+1)$

$(5+1+5)$

$(10+1)$

Financial

Reform

Do not fix budget

ceiling at $1.27 \%$

V (Greens)

ARE

UPE

PPE-Minority

PSE-Minority

Link decision to

bargaining outcome

PSE

ELDR

PPE

PPE-Minority

Fix budget ceiling at

No: UEN,

Non-attached

(PSE-Minority)

Final outcome

GUE/NGL

$1.27 \%$

members

Abstention:UEN-

Minority, GUE/NGL

\author{
Compromise \\ proposal \\ (PPE-Minority, \\ PSE-Minority)
}

PPE-Minority

\begin{abstract}
Note: We indicated the party groups according to their official abbreviations used in the European Parliament: PPE (Groupe du Parti Populaire Européen/Group of the European People's Party), PSE (Groupe du Parti des Socialistes Européens/Group of the Party of European Socialists), ELDR (Groupe du Parti des Libèraux, Démocrates et Réformateurs/Group of the European Liberal Democrat and Reform Party), Verts (Groupe des Verts/ Group of the Greens), GUE/NGL (Groupe Confédéral de la Gauche Unitaire Européenne/Gauche Verte Nordique/Confederal Group of the European United Left/Nordic Green Left), UEN (Groupe Union pour l'Europe des Nations/Union for a Europe of Nations Group), ARE (Groupe de l'Alliance Radicale Européenne/Group of the European Radical Alliance), UPE (Groupe Union pour l'Europe/Group Union for Europe).
\end{abstract}


presented a coherent and strong stance in favour of the 'regatta' approach and its commonly held view on budget matters, which regarded the 1.27 per cent as completely unrealistic.

The other smaller groups such as the Confederal Group of the European United Left/Nordic Green Left (GUE/NGL) and the Group of the European Radical Alliance (ARE) were in favour of ' $10+1$ ' and mostly critical of the 1.27 per cent line. The Europe of Nations Group (UEN) and the nonattached members were divided between opponents of the report and MEPs who abstained from the final vote. Figure 2 summarises the positions of the different party groups.

The internal divisions within the party groups were largely brought to an end through an amendment by the two main power brokers, the Socialists and the Christian Democrats. Both of the groups and therefore the majority could agree on the following 'Russian dolls' compromise. First, the enlargement process should start with a common act on 30 March 1998. Second, all countries fulfilling the Copenhagen criteria should be included in the intensified accession and negotiation process at the same time, and intensive negotiations on an individual basis should start with the most successful countries.

FIGURE 3

MEMBER STATES' POSITIONS TOWARDS THE NUMBER OF INVITED

APPLICANTS AND THE FINANCIAL ASPECTS OF THE

ENLARGEMENT PROJECT

\begin{tabular}{|c|c|c|c|}
\hline Number of applicants & $\begin{array}{l}\text { Commission } \\
\text { proposal } \\
(5+1)\end{array}$ & $\begin{array}{l}\text { 'Russian dolls' } \\
\text { approach } \\
(5+1+5)\end{array}$ & $\begin{array}{l}\text { 'Regatta' approach } \\
(10+1)\end{array}$ \\
\hline \multicolumn{4}{|l|}{$\begin{array}{l}\text { Financial } \\
\text { Reform }\end{array}$} \\
\hline $\begin{array}{l}\text { Do not fix budget } \\
\text { ceiling at } 1.27 \%\end{array}$ & & Ireland & $\begin{array}{l}\text { Portugal } \\
\text { Spain } \\
\text { (Greece) }\end{array}$ \\
\hline $\begin{array}{l}\text { Link decision to } \\
\text { bargaining outcome }\end{array}$ & & Final outcome & (Greece) \\
\hline $\begin{array}{l}\text { Fix budget ceiling at } \\
1.27 \%\end{array}$ & $\begin{array}{l}\text { Austria } \\
\text { Finland } \\
\text { France } \\
\text { Great Britain } \\
\text { Germany } \\
\text { Netherlands }\end{array}$ & Belgium & $\begin{array}{l}\text { Denmark } \\
\text { Sweden } \\
\text { Italy }\end{array}$ \\
\hline
\end{tabular}

Note: Entries are based on personal communications of the EU embassies of the respective member states, The Financial Times (15 Sept. 1997 and 12 Dec. 1997) and a declaration by German Foreign Minister Klaus Kinkel (12./13 Dec. 1997). Since Luxembourg had the presidency of the European Council, it never announced an official position and saw its role in the negotiations rather as a neutral mediator. 
When the final vote on the Oostlander/Barón Crespo report took place on 4 December, it received 369 yes votes, 28 no votes and 58 abstentions. ${ }^{37}$ This result and the discussion processes in the fractions show the conscious effort of the groups in the EP to agree on a broad consensus in order to find necessary majorities and to give the opinion of the legislature a stronger and unified appearance towards the Council and the Commission.

When the Luxembourg Council finally took place on 11-12 December 1997, the member states concentrated on agreeing on the ways and means of enlargement. By contrast, the head of government and state hardly tackled some of the related questions, such as the future financing of the Union and the organisation's institutional reform. The way out of the enlargement dilemma was a political compromise that resembled the decision by the European Parliament. Point ten of the final statement of the Council stated that the 'accession process comprising the ten Central and East European applicant States and Cyprus' will formally start with a negotiation process of the 11 applicants and that this process will be 'part of the implementation of Article $\mathrm{O}$ of the Treaty on European Union' ${ }^{38}$ The European Council, however, also upheld the distinction between two waves in the enlargement process:

The European Council has decided to convene bilateral intergovernmental conferences in the spring of 1998 to begin negotiations with Cyprus, Hungary, Poland, Estonia, the Czech Republic and Slovenia on the conditions for their entry into the Union and the ensuing Treaty adjustments.... At the same time as the above, the preparation of negotiations with Romania, Slovakia, Latvia, Lithuania and Bulgaria will be speeded up in particular through an analytical examination of the Union acquit. This preparation may also be discussed at ministerial-level bilateral meeting with the Member States of the Union.

Figure 3 summarises the member state positions and the outcome of the deliberations within the European Council. In the following, we analyse in more detail the impact that the European Parliament had on this final decision by the intergovernmentalist assembly of prime ministers and presidents of the member states.

\section{EMPLOYING PARLIAMENTARY DEBATES AS A STRATEGIC TOOL}

If one analyses the decision by the Council in detail, one can come to the conclusion that the initiative by the European Parliament had some influence on the course of events. Looking at the 'second row' of candidates - Lithuania, Latvia, Bulgaria, Romania, the Czech Republic - one can see a difference between the Commission's plans and the Luxembourg decision. 
Whereas Agenda 2000 only suggested accession partnerships, but no real accession negotiations for the 'second-class' countries, the Luxembourg Council decided to give them the official status of 'being in accession negotiations', but not in individual bilateral intergovernmental conferences, which were foreseen for the 'first-class countries'.

Although the difference between the strategies of the Commission and that of the European Council seems to be semantic at first sight, it can be argued that the European Parliament tried to make the best of its limited influence in the area of foreign policy. As one of the interview partners said: 'I think that one can see that the position of the European Council is closer to the position of the European Parliament than the one of the Commission' (IP 2) ${ }^{39}$ To some extent opinions on the influence of the legislature also depended on the institutional affiliation of our interview partners. Whereas members of the Foreign Affairs Committee of the EP underlined the effect of the EP report, Commission and Council officials only admitted some influence of the EP or described the influence indirectly, stating that: 'the EP report was something which was present in the heads' (during the Council negotiations).$^{40}$ However, the hypothesis that the European Parliament exerted a large influence on the deliberations in the European Council was also confirmed by some outside observers. The Frankfurter Allgemeine Zeitung, ${ }^{41}$ for instance, wrote that the heads of state and government of the member states corrected their positions also because of the pressure of the legislature.

The strategic intentions of the European Parliament in its vote on the enlargement issue were confirmed by several of the interviews that we conducted to gain material on the pre-bargaining positions of the decisive MEPs. One observer stated: 'I am cynical about that: they [the MEPs] sought to differentiate themselves with this report. This is related to their ambitions as an institution and the persons who do the reports' (IP 16). IP 2 confirmed the thesis put forward by Kaiser that the traditional alliance between the Parliament and the Commission is dissolving. ${ }^{42}$ Interview person 5 also said that the vote by the European Parliament resembled a successful 'PR campaign'. Another indication of the strategic use of the debate can be obtained if one compares the final result with the initial positions taken in the European Parliament. Whereas 28 per cent of the members of the Foreign Affairs Committee were initially opposed to the 'regatta approach' and the budget ceiling increase, only 6.1 per cent of all participating MEPs voted against the relatively generous Oostlander/Barón Crespo report. This indicates that the European Parliament and the party groups within the EP tried to overcome the initial division on the enlargement issue and to act as cohesively as possible. Through this consensus-building process within and between the groups and their final, widely supported position, MEPs increased their chances to be taken into account in the European Council 
negotiations in Luxembourg. The description of the discussion process in the party groups still leaves the two hypotheses concerning specialisation of committee members and socialisation of parliamentarians undiscussed so far. In the following part we look at these hypotheses and by using qualitative and quantitative data we consider whether they can serve as explanations for the actions of the European Parliament described above.

\section{CANDIDATE PRECONDITIONS: SPECIALISATION, SOCIALISATION,} THE STRUCTURE OF PARLIAMENT

One reason for the integrationist opinion of the European Parliament expressed in the Oostlander/Barón Crespo report might have been the character of the Foreign Affairs Committee as a specialised subgroup of parliamentarians in the EP. The process of selection of committee members to the EP envisages that seats are distributed according to group size. The individual groups decide amongst themselves which members should be allowed to join the committee of their preference. It it evident that the Foreign Affairs Committee is the most popular committee with the highest number of members (65) and that its composition is characterised by prominent personalities who have, for instance, served as prime ministers, foreign affairs ministers and presidents of the European Parliament. While one interview partner spoke of 'a lot of frustrated foreign ministers' (IP 9) in assessing the membership, most other interview partners probably agreed with the statement that 'all the leaders, the prominent personalities, political personalities tend to come to the Foreign Affairs Committee' (IP 3):

There are certain personalities in the Foreign Affairs Committee like Mr Tindemans from the EPP, a 'father of European integration' and Mr Hänsch, a real federalist and also the people who are really convinced of enlargement. I would say that the Foreign Affairs Committee has without doubt treated the matter a bit more political. Of course, in the Budgets or Regional Affairs Committee there are concrete aspects which you have to take into account. (IP 2) ${ }^{43}$

The popularity of the Committee cannot be derived from its formal power since it has only very limited rights and since the majority of work consists of opinions and no legislative work: 'It is a bla-bla committee', said one interview partner (IP 10), and another source told us 'that being a member in the Foreign Affairs Committee is regarded by some as the most elegant way of doing nothing' (IP 14). ${ }^{44}$ Yet the Committee can maintain its reputation as an important institution due to the prestige of the topic and to the personal gains that an MEP can derive from an expertise in foreign policy: 
... but it is high politics, it is about peace and war ... it appeals to people, it appeals to me. Popular but powerless. (IP 4)

Foreign Affairs have always been considered as good advertising from a political point of view. (IP 3)

Another explanation for the positive attitude towards enlargement could be drawn from our hypothesis about the effect that socialisation of the parliamentarians plays. Our interviews showed once again that the overlapping effects of self-selection and socialisation cannot be clearly disentangled. Some respondents were quick in asserting that MEPs are 'contaminated by this European spirit' or that even euro-sceptic parliamentarians 'change their minds'.

In the Council, they defend national interests, here in the EP it is really not done to protect your own national interest. I really believe that lots of MEPs, very many here, look at things from quite a European attitude. (IP 4)

We are building up a common culture ... the work in the European institutions is coming this way ... it is learning how to live with your former enemies with which you had your problems all your life through ... this is an experience ... but it is true ... even the people who are Euro-Sceptics when they come here and work ... they change their minds ... we discover at the end of the day ... we share many more things ... even in everyday life ... in most of the cases we are able to reach common European opinions ... and we are learning to set a new culture. (IP 8)

Yes, of course we experience socialisation. In the first three parliamentary terms when Labour was still anti-marketeer, at least at home we said amongst us: 'Ah, well, at the beginning of a term the British Labour colleagues send $2 / 3$ anti-marketeers and 1/3 promarketeers. But at the end of parliamentary term there are $1 / 3$ antimarketeers and $2 / 3$ pro-marketeers. And then we wondered how long it would take until they turned the Labour Party ... There is also the necessity to understand other points of view, to see that what you know from your home environment is not the only truth. ... You do not ignore your national interests but you realise far better which ones you can push through and which you have to drop. That takes one or two years, but then it works. (IP 14)

Yet this attitudinal change can also be a consequence of the promises that members of the Committee make in their discussion with officials from the applicant countries: 
It is only human, you meet people, you talk to them, you have dinners and you drink and you have nice discussions and of course you promise that you get whatever you can for them and then you have to give your promise and in the Parliament you have to speak for Lithuania, Latvia or Slovakia. (IP 1).

The importance of the Joint Parliamentary Committees is equally instrumental since their members 'end up being some sort of advocates on that issue'. Whether the MEPs are influenced by the new experiences or the new incentive structure remains, however, difficult to distinguish. The country rapporteurs and the members of Joint Parliamentary Committees in particular gain a wider knowledge of other matters and simultaneously become dependent on another source of influence:

There is also another point which has to be taken into account. You know, in the EP the Joint Parliamentary Committees are really working, there are good relations between the parliaments. That means that parliamentarians are very well aware of the situation in that country, the discussion going on is very well heard and they can see what the real situation is in that country. For that reason it was quite normal and quite easy to take a decision on that, to find out that our position can be different from the Commission. ... For the Commission it is easy to say: You come in, you stay out. For a person who has to stress the political ties between the Union and the candidates. it is a problem to say: you are better than the other one. You don't really believe in the technical, economical, political, social reasons outlined by the Commission. (IP 3)

you know we have these Joint Parliamentary Committees ... and the risk of becoming advocates of these countries is big in the case of the parliament ... you know that some people consider us as some sort of fathers - godfathers - of the people coming. (IP 8)

Similar processes were observed when the 11 country rapporteurs gave statements on the situation of the applicant countries. Their work involved a lot of contacts with people from those countries and this experience widened their knowledge on the situation of the applicants. This seemed to influence their opinion considerably:

Basically, it seems to be so that when we have rapporteurs they become somehow very sympathetic towards the country they are working with. Someone sitting in the Estonian, Latvian or Lithuanian delegation, they start to advocate their case, the case of the country they are dealing with. ... And I would say if there is any special 
motive, why some members wanted to have this decrease in the difference, because they wanted to improve the position of their client country so to say. (IP 1)

I remember early changes of view when for instance Mr Wiersma (the Dutch country rapporteur in charge of Slovakia) was quite critical of the Slovak regime and I have to say that the guy changed quite a lot during the work on that report. (IP 10)

These responses suggest that parliamentarians are easily influenced through outside experiences. What this perspective neglects is the need to find coalitions on specific proposals and the tendency that members of the European Parliament do not want to lose face in their day-to-day interactions with their colleagues. When talking to our interview partners about socialisation, some of their remarks indicated that intra-group pressure is an equally good cause of an integrationist attitude as learning and socialisation:

What would be very interesting to study more closely is what happens with so-called no-sayers when they come to parliament. ... Because you develop personal friendships in the groups and it must be more and more difficult to sit and disagree with everybody after a certain time ... especially if you become friends. (IP 10)

This brings us back to our third hypothesis that the institutional provision of multinational party groups is effectively responsible for coherent voting behaviour of the MEPs. To carry out effective legislative work, the transnational party groups are challenged to form a cohesive group where the majority of group members from various nationalities support the group proposal. The groups serve as principals for their agents, the group members. Party groups play an important role in informing members, distributing positions and formulating common positions. Members accordingly depend on this infrastructure if they want to succeed within the legislature. The agents are furthermore disciplined by 'whips' of the party groups who pay attention to voting according to the agreed group consensus. Therefore, Members of the European Parliament can be regarded as agents who serve multiple principals.

To gain a clear understanding of the relative importance of principal-agent relations, we supplement this qualitative evidence with some logit regression results. The independent variable in the subsequent analysis is whether the initial position of a member of the Foreign Affairs Committee corresponds to the Commission proposals or not. We conducted these tests for both disputed dimensions, the number of negotiation partners and the flexibility of the budget ceiling. Table 1 reports the results that were obtained from the analysis of the positions on the first issue. 
To estimate the relative impact, we distinguish four models. The national influence model is the baseline model which allows us to assess the relative impact of the competing national and transnational principals on the attitude of the MEPs. We thus control throughout the entire analysis the influence that the attitude of the government and the transnational party have on the decision of the individual committee member. The inclusion of this latter variable can be justified on the grounds that MEPs are forward-looking individuals who anticipate the attitude of their own colleagues in the party group. The national influence model further controls for the role that the government party might play in the MEP's mind. As Hix and Lord have shown, the relationship of a parliamentarian to his or her government mattered a great deal in the vote on the confirmation of Jacques Santer as the incoming president of the European Commission. ${ }^{45}$ Finally, the baseline model controls for the impact that the electoral system has on the MEP calculation. Bowler and Farrell demonstrate that electoral rules affect the importance that MEPs attribute to regional, national and transnational interest groups ${ }^{46}$ Unsurprisingly, MEPs who were elected through majority rule are much more responsive to their voting districts than parliamentarians who became members in political systems that rely on proportional voting.

The second model then evaluates whether the inclusion of two socialisation variables makes a difference. The first predictor is the length of the individual members' mandate. Although we admit that this is a crude measure, no alternative indicator has yet been proposed in the literature. A second measure of socialisation is a dummy variable that measures whether or not a MEP has been serving as a rapporteur for a specific applicant country. While the specialisation model controls for the eventual impact that a prior experience in the government of the home country might have on the position, the full model compares the relative weight of all independent measures. The two tables also report the influence that the contending theories of MEP behaviour let us expect for the different variables.

The results from this first preliminary analysis lend no support to the socialisation hypothesis if the related indicator is measured in the conventional fashion as the number of years that an MEP has served in the European Parliament. The alternative measure - an MEP's eventual experience as a rapporteur - equally does not bear a significant impact. The initial positions, on the other hand, strongly support the opinion that the home government has on the topic under consideration. This suggests that the parliamentarians are really thinking more in terms of their home countries than most supranationalist studies let us think. The specialisation variable which is crudely operationalised in terms of government experience equally does not have the expected impact. On the contrary, former ministers and prime ministers are more reluctant and tend to opt for 
TABLE 1

IMPACT OF SOCIALISATION, GOVERNMENT OPINION, SPECIALISATION AND COUNTRY ATTRIBUTES ON THE INITIAL POSITION REGARDING THE NUMBER OF NEGOTIATION PARTNERS

\begin{tabular}{|c|c|c|c|c|c|}
\hline Predictor variables & $\begin{array}{l}\text { Expected } \\
\text { influence }\end{array}$ & $\begin{array}{l}\text { National } \\
\text { model }\end{array}$ & $\begin{array}{l}\text { Socialisation } \\
\text { model }\end{array}$ & $\begin{array}{l}\text { Specialisation } \\
\text { model }\end{array}$ & $\begin{array}{l}\text { Full } \\
\text { model }\end{array}$ \\
\hline Government opinion & - & & $\begin{array}{l}-3.62 * * * \\
(1.10)\end{array}$ & $\begin{array}{l}-3.80^{* * * *} \\
(1.15)\end{array}$ & $\begin{array}{l}-5.98 * * * \\
(2.10)\end{array}$ \\
\hline Party group opinion & - & $\begin{array}{l}-0.94 \\
(0.76)\end{array}$ & $\begin{array}{l}-0.85 \\
(0.78)\end{array}$ & $\begin{array}{l}-1.60^{* * *} \\
(0.91)\end{array}$ & $\begin{array}{l}-1.38 \\
(0.96)\end{array}$ \\
\hline Government party & + & $\begin{array}{l}0.36 \\
(0.78)\end{array}$ & $\begin{array}{l}0.57 \\
(0.83)\end{array}$ & $\begin{array}{l}-0.70 \\
(1.12)\end{array}$ & $\begin{array}{l}-0.49 \\
(1.14)\end{array}$ \\
\hline Founding member state & - & $\begin{array}{l}-2.99 * * * \\
(1.05)\end{array}$ & $\begin{array}{l}-3.17 * * * \\
(1.17)\end{array}$ & $\begin{array}{l}-5.27 * * * \\
(2.14)\end{array}$ & $\begin{array}{l}-5.36^{* *} \\
(2.29)\end{array}$ \\
\hline Electoral system & + & $\begin{array}{l}-0.49 \\
(0.67)\end{array}$ & $\begin{array}{l}-0.62 \\
(0.76)\end{array}$ & $\begin{array}{l}-1.47 \\
(1.03)\end{array}$ & $\begin{array}{l}-1.40 \\
(1.18)\end{array}$ \\
\hline Length of mandate & + & - & $\begin{array}{l}-0.07 \\
(0.08)\end{array}$ & - & $\begin{array}{l}-0.05 \\
(0.10)\end{array}$ \\
\hline Rapporteur & + & - & $\begin{array}{l}-0.86 \\
(0.96)\end{array}$ & - & $\begin{array}{l}-1.78 \\
(1.14)\end{array}$ \\
\hline Government experience & + & - & - & $\begin{array}{l}-1.70^{*} \\
(0.96)\end{array}$ & $\begin{array}{l}-1.85^{*} \\
(1.04)\end{array}$ \\
\hline Constant & & $\begin{array}{l}9.20 * * * \\
(3.35)\end{array}$ & $\begin{array}{l}10.54 * * * \\
(4.01)\end{array}$ & $\begin{array}{l}17.54 * * * \\
(6.94)\end{array}$ & $\begin{array}{l}18.33^{* *} \\
(7.81)\end{array}$ \\
\hline $\begin{array}{l}\text { Log-likelihood } \\
\text { Number of cases }\end{array}$ & & $\begin{array}{l}-23.82 \\
60\end{array}$ & $\begin{array}{l}-22.92 \\
60\end{array}$ & $\begin{array}{l}-17.72 \\
55\end{array}$ & $\begin{array}{l}-16.27 \\
55\end{array}$ \\
\hline
\end{tabular}

Note: *** $\mathrm{p}<.01 ; * * \mathrm{p}<.05 ; * \mathrm{p}<.10$.

The dependent variable takes the value of 0 if a MEP is in favour of the Commission proposal ( 1 otherwise). 'Government opinion' takes the value of 1 if the government in the home state of the MEP supports the Commission ( 0 otherwise); 'party group' amounts to 1 if the party group is in favour of this proposal ( 0 otherwise); 'government party' measures 1 if the individual MEP's party was in the government of the home country at the time of the vote ( 0 otherwise); 'founding member state' is 1 if the MEP comes from one of the six founding members of the organisation ( 0 otherwise); 'electoral system' is 2 if the MEP's member state relies on proportional voting without preferential votes, 1 if the MEP's member state employs proportional voting with preferential votes, and 0 in case of majority voting.

Length of mandate is measured in years, and rapporteur is $1(0)$ if the MEP was one of the 11 country rapporteur or not, and 'government experience' is 1 if the MEP has served in a government in his or her home state at some time ( 0 otherwise).

the Commission opinion. The strong influence of the national background also becomes clear through the tendency of MEPs from founding member states to opt for the expansive option rather than the timed Commission proposal. Hence, the European Parliament is clearly divided along national lines, although the final voting behaviour only reflects deep ideological divisions. Since neither socialisation nor specialisation have repercussion in the opinion-building process, the transnational incentive structure is the decisive force that turns MEPs into the supranational camp despite the strong national pressure. 
Similar results can be obtained with regard to the second dimension. The most important difference between Table 1 and Table 2 is, however, that the indicator for the socialisation hypothesis points in the wrong direction. The smaller number of cases is largely due to the fact that information could not easily be obtained on this highly redistributive issue. The statistical results also confirm that the initial positions were largely influenced by national considerations. The final integrationist view of the European Parliament thus has to result from other factors. Contrary to the findings of Hix and Lord, it does not play a relevant role in our study on MEPs' voting

TABLE 2

IMPACT OF SOCIALISATION, GOVERNMENT OPINION, SPECIALISATION AND COUNTRY ATTRIBUTES ON THE INITIAL POSITION ON THE FLEXIBILITY OF THE BUDGET CEILING

\begin{tabular}{|c|c|c|c|c|c|}
\hline Predictor variables $\mathrm{E}$ & $\begin{array}{l}\text { Expected } \\
\text { influence }\end{array}$ & $\begin{array}{l}\text { National } \\
\text { influence }\end{array}$ & $\begin{array}{l}\text { Socialisation } \\
\text { effects }\end{array}$ & $\begin{array}{l}\text { Specialisation } \\
\text { effects }\end{array}$ & $\begin{array}{l}\text { Full } \\
\text { model }\end{array}$ \\
\hline Government opinion & - & $\begin{array}{l}-3.55^{* *} \\
(1.41)\end{array}$ & $\begin{array}{l}-5.54 * * \\
(2.40)\end{array}$ & $\begin{array}{l}-3.64 * * \\
(1.48)\end{array}$ & $\begin{array}{l}-6.02 * * \\
(2.83)\end{array}$ \\
\hline Party group opinion & - & $\begin{array}{l}-2.91 * * \\
(1.39)\end{array}$ & $\begin{array}{c}-3.00^{*} \\
(1.60)\end{array}$ & $\begin{array}{c}-2.60^{*} \\
(1.41)\end{array}$ & $\begin{array}{l}-3.18 \\
(1.72)\end{array}$ \\
\hline Government party & + & $\begin{array}{l}-1.81 \\
(1.12)\end{array}$ & $\begin{array}{l}-2.11 \\
(1.34)\end{array}$ & $\begin{array}{l}-1.44 \\
(1.17)\end{array}$ & $\begin{array}{l}-1.07 \\
(1.46)\end{array}$ \\
\hline Founding member state & - & $\begin{array}{l}-0.25 \\
(1.18)\end{array}$ & $\begin{array}{l}-2.61 \\
(2.03)\end{array}$ & $\begin{array}{c}-0.48 \\
(1.35)\end{array}$ & $\begin{array}{l}-2.69 \\
(2.38)\end{array}$ \\
\hline Electoral system & + & $\begin{array}{c}0.61 \\
(0.76)\end{array}$ & $\begin{array}{l}-0.65 \\
(1.01)\end{array}$ & $\begin{array}{c}0.30 \\
(0.90)\end{array}$ & $\begin{array}{l}-0.83 \\
(1.13)\end{array}$ \\
\hline Length of mandate & + & - & $\begin{array}{l}-0.44^{*} \\
(0.25)\end{array}$ & - & $\begin{array}{l}-0.59^{*} \\
(0.34)\end{array}$ \\
\hline Rapporteur & + & - & $\begin{array}{c}2.80 \\
(2.19)\end{array}$ & - & $\begin{array}{c}3.58 \\
(2.77)\end{array}$ \\
\hline Government experience & + & - & - & $\begin{array}{c}0.16 \\
(1.32)\end{array}$ & $\begin{array}{c}1.78 \\
(1.65)\end{array}$ \\
\hline Constant & & $\begin{array}{c}2.30 \\
(3.32)\end{array}$ & $\begin{array}{l}12.39 * \\
(6.59)\end{array}$ & $\begin{array}{c}3.02 \\
(4.07)\end{array}$ & $\begin{array}{l}13.19^{*} \\
(7.81)\end{array}$ \\
\hline Log-likelihood & & -12.87 & -9.74 & -11.88 & -8.13 \\
\hline Number of cases & & 39 & 39 & 35 & 35 \\
\hline
\end{tabular}

Notes: $* * * \mathrm{p}<.01 ; * * \mathrm{p}<.05 ; * \mathrm{p}<.10$.

Standard error in parentheses. The dependent variable takes the value of 0 if a MEP is in favour of the Commission proposal ( 1 otherwise). 'Government opinion' takes the value of 1 if the government in the home state of the MEP supports the Commission ( 0 otherwise); 'party group' amounts to 1 if the party group is in favour of this proposal ( 0 otherwise); 'government party' measures 1 if the individual MEP's party was in the government of the home country at the time of the vote ( 0 otherwise); 'founding member state' is 1 if the MEP comes from one of the six founding members of the organisation ( 0 otherwise); 'electoral system' is 2 if the MEP's member state relies on proportional voting with preferential votes, 1 if the MEP's member state employs proportional voting without preferential votes, and 0 in the case of majority voting. Length of mandate is measured in years, and rapporteur is $1(0)$ if the MEP was one of the 11 country rapporteur or not, and 'government experience' is 1 if the MEP has served in a government in his or her home state at some time (0 otherwise). 
behaviour whether their own party is represented in the national government and is therefore directly involved in the Council negotiations. ${ }^{47}$ Further, electoral systems do not seem to matter in a vote on a single issue. This casts some doubts on whether the survey results of Bowler and Farrell can be used in other contexts. ${ }^{48}$

Looking at the different national opinions in the Foreign Affairs Committee, the cohesive appearance of the party groups seems to be due to the effective consensus-building mechanisms within the party groups. In the end, it seems as if the internal reputation that an MEP can gain matters a great deal. The sanctioning mechanism of the party groups seems to be the decisive force that changes the attitudes of European legislators.

\section{CONCLUSION}

This article has shown that the European Parliament has in the current enlargement debate largely profited from the oldest of all resources that are in the hands of a parliament - words. Although the legislature does not possess agenda-setting power in the domain of foreign policy, it made a serious attempt to change the status quo through an integrationist vote supported by a wide majority. The European Parliament was only able to behave in this way because party groups forced members with more rigid convictions to alter their initial preference. Neither the traditional socialisation nor the alternative specialisation hypotheses receive convincing evidence to explain the surprisingly integrationist and united attitude of the European Parliament.

Although these results are limited to one decision-making case, they allow us to derive some general conclusions for the study of regional integration. First, the paper sketches some microfoundations of the behaviour of the European Parliament which often decides in a more supranational manner than distributional theories of legislative behaviour suggest. The analytic framework suggests that MEPs frequently face a tradeoff between national and transnational interests. Since re-election considerations sometimes do not loom large enough, they can occasionally display a certain disrespect towards salient constituency interests and can behave according to group demands.

Second, our results lend critical support to some earlier claims that have been made with regard to the role of the European Parliament in the integration process. Sandholtz, for instance, claims that the legislature has been able to influence European Council negotiations over monetary union in a decisive fashion. Our analysis also provides a causal link between the behaviour of the European Parliament and the intergovernmentalist bargaining processes..$^{49}$ 
Third, party group discipline might be one of the overlooked factors that strengthen the process of European integration. The pressure which the transnational party groups exert on their members forces the national groups to search for a transnational consensus and to part from their national stances. It is conceivable that national voting behaviour would be much more predominant if the transnational institutional structure of the EP were different. This finding offers interesting parallels to the debate on the European Court of Justice where the strategic moves by the judges are increasingly linked to similar considerations ${ }^{50}$ Fourth and finally, the results presented in this article suggest that voting according to national lines will become more important if the European Parliament becomes more powerful or if constituency demands start to override party group pressure. It is highly likely that the transnational drive towards more integration will vanish when the European Parliament becomes a fully emancipated power player in the European Union. The decisive and positive influence of the legislature on the integration process might ultimately be as transitory as the impact that the European Court of Justice has had during an earlier period.

\section{APPENDIX}

Interviews were carried out in Brussels with the following persons:

\section{MEPs}

- Enrique Barón Crespo, PSE, Spain, 30-4-98

- Staffan Burenstam Linder, PPE, Sweden, 29-4-98

- Katerina Daskalaki, UPE, Greece, 30-4-98

- Gary Titley, PSE, United Kingdom, 30-4-98

- Paavo Väyrynen, ELDR, Finland, 28-4-98

- Catherine Lalumière, ARE, France, 30-4-98

- Jelle Bakker, Assistant of Arie Oostlander, PPE, Netherlands

- Klaus Hänsch, PSE, Germany, 14-5-98

\section{Advisors/Civil Servants}

- Mia Asenius, Political Advisor for Foreign Affairs, ELDR, 30-4-98

- Paolo Bergamaschi, Political Advisor for Foreign Affairs, Green Group, 29-4-98

- Gianluca Brunetti, Administrator, Committee for Foreign Affairs, Security and Defense Policy, 30-4-98

- Andreas-Renatus Hartmann, Political Advisor for Middle and Eastern Europe, PPE, 29-4-98

- Bruno Marasa, Political Advisor for Foreign Affairs, PSE, 29-4-98

- Arthur Hildebrandt, Political Advisor for Foreign Affairs, PPE, 13-5-98

- Christian Braun, Luxembourg delegation at the European Communities, 7-9-1998 
- Michael Leigh, Councillor in Cabinet of Commissioner van den Broek, European Commission, 8-9-1998

- Norbert Schwaiger, Head of Press Service of Council of Ministers, 15$12-98$

\section{NOTES}

1. From our conversation with interview person 8 .

2. M.A. Pollack, Constructivism, Social Psychology, and Elite Attitude Change: Lessons from an Exhausted Research Program (Baltimore, MD, 1998)50 for example K. Alter, 'Who are the "Masters of the Treaty"? European Governments and the European Court of Justice', International Organization, 52/1 (1998), pp.121-47.

3. For example, C. Crombez, 'Legislative Procedures in the European Community', British Joumal of Political Science, 26 (1996), pp.199-228; P. Moser, 'The European Parliament as a Conditional Agenda Setter: What Are the Conditions? A Critique of Tsebelis (1994)', American Political Science Review, 90/4 (1996), pp.834-8; P. Moser, 'The Benefits of the Conciliation Procedure for the European Parliament: Comment to George Tsebelis', in Decision Rules in the European Union (Zürich: Rüegger Außenwirtschaft $=$ the Swiss Review of International Economic Relations, 1997), pp.57-62; G. Schneider, 'The Limits of Self-Reform: Institution-Building in the European Union', European Journal of International Relations, 1/1 (1995), pp.59-86; B. Steunenberg, 'Decision Making Under Different Institutional Arrangements: Legislation by the European Community', Journal of Institutional and Theoretical Economics (JTTE), 150/4 (1994), pp.642-69; G. Tsebelis, 'The Power of the European Parliament as a Conditional Agenda Setter', American Political Science Review, 88/1 (1994), pp.128-42; G. Tsebelis, 'Maastricht and the "Democratic Deficit", Aussenwirtschaft, 52 (1997), pp.29-56. 49 W. Sandholtz, "Choosing Union: Monetary Politics and Maastricht', International Organization, 47/1 (1993), pp.1-39.

4. Article 80 of the Treaty on the European Union states that the EP has no right to put amendments to an Accession treaty. Articles 89 and 90 respectively give the right to demand a discussion or to express opinions on the treaties.

5. This term was coined by A. Moravcsik, 'Explaining International Human Rights Regimes', European Journal of International Relations, 1/2 (1995), pp.157-89.

6. The tradition largely started with $\mathrm{H}$. Kerr, "Changing Attitudes Through International Participation: European Parliamentarians and Integration', International Organization, 27 (1973), pp.45-83. Recent contributions include R. Scully, 'Becoming Europeans? Socialisation and Institutional Loyalty Among European Parliamentarians' (unpublished manuscript, 1997); and S. Scarrow 'Political Career Paths and the European Parliament', Legislative Studies Quarterly, 22/2 (1997), pp.253-63.

7. For example J.T. Checkel, 'International Norms and Domestic Politics: Bridging the Rationalist-Constructivist Divide', European Journal of International Relations, $3 / 4$ (1997), pp.473-95.

8. Pollack, Constructivism, Social Psychology, and Elite Attitude Change.

9. B.R. Weingast and W.J. Marshall, 'The Industrial Organization of Congress or Why Legislatures Like Firms Are Not Organized as Markets', Journal of Political Economy, 96/11 (1988), pp.132-63.

10. S. Hix and C. Lord, 'The Making of a President: The European Parliament and the Confirmation of Jacques Santer as President of the Commission', Government and Opposition, 31/1 (1996), pp.62-76.

11. S. Bowler and D.M. Farrell, 'Legislator Shirking and Voter Monitoring: Impacts of European Parliament Electoral Systems upon Legislator-Voter Relationships', Journal of Common Market Studies, 31/1 (1993), pp.45-69.

12. T. Raunio, Party Group Behaviour in the European Parliament. An Analysis of Transnational Political Groups in the 1989-1994 Parliament (Tampere: University of Tampere Press, 1996), pp.202-5. 
13. Raunio, Party Group Behaviour in the European Parliament.

14. Europäische Kommission, Agenda 2000 - Band I: Eine Stärkere und Erweiterte Union. DOC/97/6 and Europäische Kommission, Agenda 2000 - Pressemitteilung IP/97/660 - Die Europäische Kommission legt ihre Mitteilung 'Agenda 2000 - Eine stärkere und erweiterte Union' vor, 16 July 1997.

15. In this analysis we do not take into account the new stance on enlargement of the new Commission under Romano Prodi. This new stance wants to abolish the concept of groups and envisages to start negotiations with six more candidates in 2000. Yet this position has to be backed by the Helsinki Summit in December 1999.

16. Financial Times, 10 and 11 July 1997.

17. The European Council had agreed on the 1.27 per cent ceiling at the Edinburgh summit of 1992. The formula means that the sum of own resources (income from EU customs duties, agricultural levies applied on the import of agricultural products from outside the EC, the proportion of national receipts from value-added tax and direct contributions from member states) should not exceed 1.27 per cent of the Gross National Product (GNP) of all EU member states.

18. The European Commission called these states, in a vain attempt at politically correct camouflage, the 'pre-ins'.

19. Financial Times, 15 and 16 Sept. 1997.

20. The status of the European Conference became another bone of contention between countries who were in favour of offering Turkey a place in this institution (like France) and opponents of closer links with Turkey (Greece and Germany). Greece made its point very clear at the beginning of December when it suggested vetoing the enlargement process completely in case of Turkey's participation in the European Conference.

21. The Times, 7 Dec. 1997.

22. For the abbreviations of the party groups see note to Figure 2.

23. Europäisches Parlament, Bericht über die Mitteilung der Kommission 'Agenda 2000 - Eine stärkere und erweiterte Unio' - Ausschuß für auswärtige Angelegenheiten, Sicherheit und Verteidigungspolitik, A4-368, PE224.339/DEF(1997). Berichterstatter: Arie Oostlander, Enrique Barón Crespo. See also Europäisches Parlament, Änderungsanträge 1-106 zum Bericht Oostlander/Barón Crespo A4-0368/97. PE 264.941/1-106 (1997)

24. The Socialists were able to write four country reports, the EPP three. The remaining groups (UPE, GUE/NGL, Greens, ELDR) were responsible for one report each. The rapporteurs were Jörn Donner (FIN/SPE) for Estonia, Magdalena Hoff (D/SPE) for Poland, Roberto Speciale(I/SPE) for Slovenia, Jan Marius Wiersma(NL/SPE) for Slovakia, Otto von Habsburg(D/EPP) for Hungary, Frode Kristoffersen(DK/EPP) for Lithuania, Pierre Bernard Raymond(F/EPP) for Rumania, Ernesto Caccavale(I/UPE) for Latvia, Carlos Carnero Gonzalez (E/GUE/NGL) for Czech Republic, Magda Aelvoet(DK/V) for Bulgaria, JanWillem Bertens(NL/ELDR) for Cyprus.

25. Europäisches Parlament, Bericht über die Agenda 2000: Finanzrahmen der Union für den Zeitraum 2000-2006 und künftiges Finanzierungssystem, HaushaltsausschuB, A4-331, PE 223.701 (1997), Berichterstatter: Joan Colom i Naval, and Europäisches Parlament, Änderungsanträge 1-38 zum Bericht Colom i Naval, A4-331/97. PE 264.940/1-38.

26. Europäisches Parlament 1997, Änderungsanträge 1.506 zum Berichtsentwurf Oostlander/Barón Crespo, 7 Nov. 1997. PE 224.339/Änd.1-506. Ed. Sicherheit und Verteidigungspolitik Ausschuß für Auswärtige Angelegenheiten.

27. Press release of the Socialist Group, 6 Nov. 1997.

28. Frankfurter Allgemeine Zeitung, 12 Nov. 1997.

29. Article 9 in the Colom i Naval report, A4-331/97/Part A+B, PE 223.701/end/Teil A+B.

30. Frankfurter Allgemeine Zeitung, 12 Nov. 1997, Press release of the EPP group, 12 Nov. 1997.

31. H.-G. Poettering, 'Der Beitritt der Länder Mittel- und Osteuropas zur Europäischen Union eine Historische Aufgabe', in CDU/CSU, Weichenstellung für das 21. Jahrhundert (Köln/ Weimar/Wien: Böhlan Verlag, 1998), pp.45-51.

32. Spencer told the European Parliament: 'We said that we want everyone in the enlargement process, we want to open negotiations with all the applicants except Slovakia and we want 
to open intensive negotiations with the Five-Plus-One-countries identified by the Commission. As I understand it, yesterday's meeting of COREPER, produced a diagram: I have not had the privilege of seeing that diagram officially but if I understand it correctly it may well be the precursor of what is agreed in the Luxembourg Summit. It seems to me very much to reflect the Russian dolls approach. As I understand it, they are suggesting a European conference, which is the enlargement process, with a side helping of extra political support for Turkey. Then in the second doll, free accession discussions with the Ten-Plus-One, supplemented by additional preparatory discussions with those countries which have not immediately been selected for the opening of Article $O$ negotiations. It is that third doll, that central doll, the need to proceed with those negotiations with the Five-Plus-One countries which I particularly welcome here tonight.' Europäisches Parlament, Verbatim Report of the Proceedings, 3 Dec. 1997, p.47.

33. Press release No 180 of the UPE group, La lettre de Strasbourg, Juillet 1997.

34. Europäisches Parlament, Verbatim report of the proceedings, 3 Dec. 1997, p.18.

35. Press release, Spokesman's Office ELDR, 13 Nov. 1997.

36. MEP Teverson (ELDR/GB) told the plenary on 3 Dec. 1997: 'I believe that the $1.27 \%$ ceiling is very realistic but to actually achieve it ... real internal reforms have to be delivered ... so, yes, keeping within $1.27 \%$ must be kept a firm target but at the death it must not become an unyielding barrier that prevents enlargement.' Europäisches Parlament, Verbatim report of the proceedings, 3 Dec. 1997, p.53.

37. For the votes and proceedings see Europäisches Parlament, Protokoll der Sitzung vom Donnerstag, 4. Dezember 1997, Teil 1, PE 264.945 and Europäisches Parlament, Protokoll der Sitzung vom Donnerstag, 4. Dezember 1997, Teil 1I, Angenommene Text and Europäisches Parlament, Protokoll der Sitzung vom Mittwoch, 3. Dezember 1997. PE 264.944, Europäisches Parlament, Protokoll. Ergebnis der namentlichen Abstimmungen, 4.12.1997, PE 264.945.

38. Luxemburg European Council, Presidency Conclusions, 12 and 13 Dec. 1997. The two following quotes are also from the Presidency Conclusions. A specific pre-accession strategy for Cyprus is outlined in point 22 of the Declaration which included some more detailed and specific provisions for Cyprus' needs. An 'enhanced pre-accession strategy' was offered to the Central and Eastern European countries; this new strategy includes the already existing Europe Agreements, new accession partnerships and increased pre-accession aid.

39. Own translation from French original.

40. Interview partners 15,16 and 17.

41. Frankfurter Allgemeine Zeitung, 15 Dec. 1997.

42. D. Kaiser, 'Institutioneller Wandel im Europäischen Politikprozeß. Europäisches Parlament und Kommission - Ende einer natürlichen Allianz' (Diplom. Thesis, Department of Politics and Management, University of Konstanz, 1996).

43. Own translation from French original.

44. Own translation from German original.

45. Hix and Lord, 'The Making of a President'.

46. Bowler and Farrell, 'Legislator Shirking and Voter Monitoring:Impacts of European Parliament Electoral Systems upon Legislator-Voter Relationships.'

47. Hix and Lord, 'The Making of a President'.

48. Bowler and Farell, 'Legislator Shirking and Voter Monitoring:Impacts of European Parliament Electoral Systems upon Legislator-Voter Relationships.'

49. W. Sandholtz, 'Choosing Union: Monetary Politics and Maastricht', International Organization, 47/1 (1993, pp.1-39.

50. For example K. Alter, 'Who are the "Masters of the Treaty"? European Governments and the European Court of Justice', International Organization, 52/1 (1998), pp.121-47. 